\title{
IDENTIFICATION OF POSSIBLE DITCH CULVERT LOCATIONS USING LIDAR DATA
}

\author{
Raitis Melniks, Janis Ivanovs, Andis Lazdins \\ Latvian State Forest Research Institute "Silava", Latvia \\ raitis.melniks@silava.lv, janis.ivanovs@silava.lv, andis.lazdins@silava.lv
}

\begin{abstract}
The aim of this study is to investigate and adapt existing methods for the identification of ditch connections and culverts using LiDAR (Light detection and ranging) data. The research area is located in Daugavpils region, Kalupe parish and covers area of $25 \mathrm{~km}^{2}$. Two methods are used, the first one is based on a ditch network analysis previously obtained from LiDAR data and the second is based on digital elevation model (DEM) processing. The first method correctly identified $37 \%$ of the culverts, as well as other possible ditch connections. The second method by its working principle is difficult to apply to the specific objective in the conditions of Latvia, but it is possible to supplement the first method. A combination of both methods identified $47 \%$ of the ditches in the pilot area. Raster histograms are used to estimate efficiency of both methods. It has been concluded that these methods can be used with some caution in Latvia conditions for DEM correction before modelling and can make significant difference in surface flow, but there are still a number of challenges to do so automatically and correctly.
\end{abstract}

Keywords: DEM, ditch, connectivity, depressions

\section{Introduction}

Previous studies have been done to improve the GIS algorithms used in DEM processing to remove and smooth human-made elevations $[1 ; 2]$. The purpose of such algorithms is to provide continuity of water flow in the terrain model to estimate soil moisture conditions in the area $[3 ; 4]$. Different tools have been developed to fill depressions, thereby eliminating the dam effect due to elevation, as well as tools to prevent depression by automatically getting rid of the disturbance in the model $[4 ; 5]$. Such automated tools, according to their developers and researchers who have used them, are unable to determine the correct places to get rid of elevation, and to correct terrain patterns in places where there are no human-made elevations, thus creating a misleading picture of the real situation $[6 ; 7]$.

Previous studies on the identification of culverts in the digital elevation model have begun relatively recently $[8 ; 9]$. Prior to this, in studies that have identified ditch network, the need to identify culverts has only fit into future plans [10-12]. The ability to determine the flow direction from the start to the end of a ditch is an important factor in the identification of culverts. In the Netherlands [9], several other approaches were used to determine the direction of flow at ditch ends. For example, each individual section of a ditch can only be connected to one of the nearby end sections, only sections with a defined maximum height difference can connect, and the connection cannot cross other existing sections of the ditch. Such conditions avoid a variety of interferences when connecting ditches and combine only ditches in the vicinity and flowing in one direction. The obtained ditch connection points were tested by field measurements. Of the 68 culverts obtained by modelling, only 23 were found [9]. However, it should be noted that in this study ditch connections were searched within a radius of $100 \mathrm{~m}$, thus creating a relatively high number of false connections.

Using existing methods for processing LiDAR data, researchers typically manually modify the terrain model to ensure the hydrological integrity of the data. It can produce good results, but is a very laborious process. Until recently, the potential of using a breaching algorithm to improve hydrological modelling capabilities on agricultural lands was exploited by German researchers [13] without the use of additional data sources and without significant manual manipulation.

\section{Materials and methods}

The study area is located in Latvia, Daugavpils region, Kalupe parish, and is $25 \mathrm{~km}^{2}$ large (Fig 1). It is dominated by glaciolacustrine and bog sediments, which in turn are predominantly wet, drained mineral and organic soils. Considering the prevailing forest types and the Quaternary sediments on which they are located, it can be concluded that an assessment of the feasibility of modelling the location of drainage systems, its condition and moisture conditions in the area is essential. 


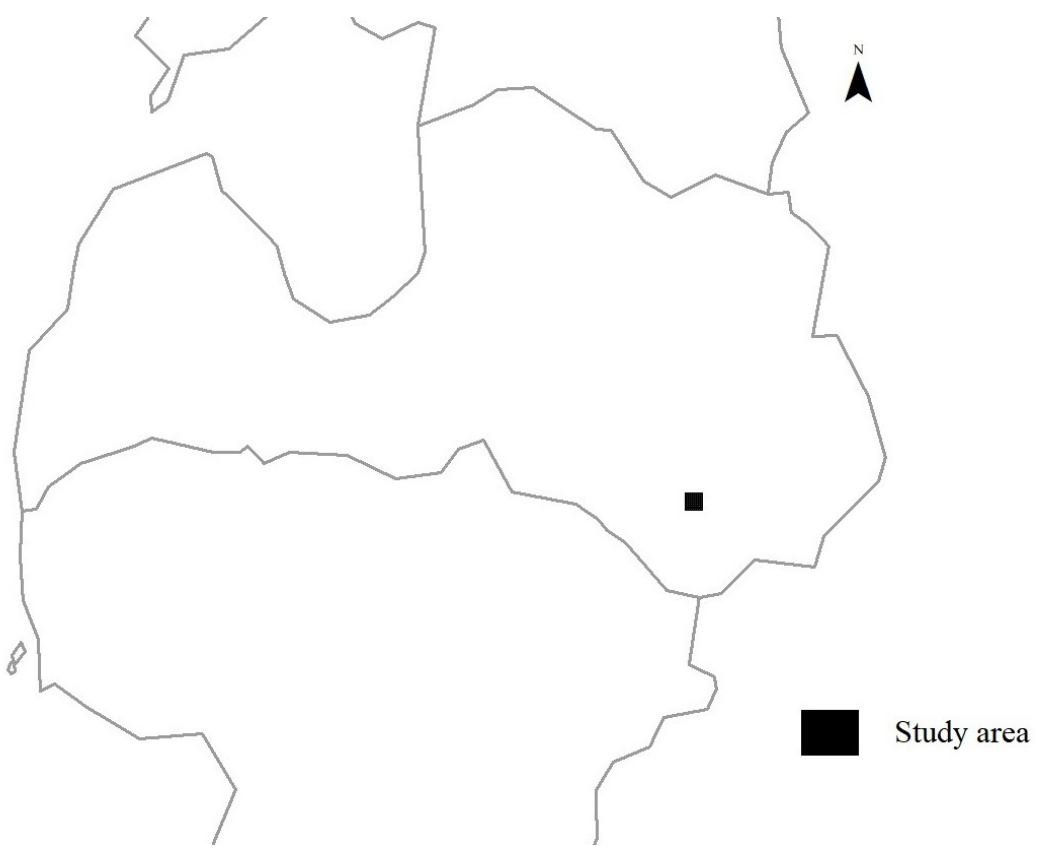

Fig. 1. Location of study area

The LiDAR data required for the development of the digital elevation model (DEM) were obtained from the Latvian Geospatial Information Agency (LGIA). The LiDAR data used have a vertical accuracy of $12 \mathrm{~cm}$ and a horizontal accuracy of $36 \mathrm{~cm}$ (2 sigmas with $95 \%$ confidence in the National Geodetic Network). The minimum requirements for point density are $4 \mathrm{p} \cdot \mathrm{m}^{-2}$ and the average ground point density is $1.5 \mathrm{p} \cdot \mathrm{m}^{-2}$ [14]. In this study two principles of DEM correction are tested. The first method has been developed in the framework of this work, which uses an automatically generated ditch network to identify culverts, where the vector data correspond to the ditch bed in the digital elevation model. The data must conform to the terrain model used to make the necessary corrections to the DEM in subsequent data processing steps and in hydrological modelling. The pre-existing ditch network is essential to identify the possible locations of the ditches using this method. In the first stage of data processing, ditch elements were found, which were located up to $20 \mathrm{~m}$ apart, searching at an angle of $120^{\circ}$ using ArcGIS extension ArcScan environment. This approach makes it possible to identify possible locations for culverts in the case of a road crossing a ditch with a roadside ditch. This method does not identify culverts in situations, where ditches are placed parallel to one another and are incapable of intersecting at a given distance (Fig. 2). The resulting culvert data can be used to modify the terrain model using tools such as Burn Streams at Roads in Whitebox GAT, which also requires vector data about roads that are crossing ditches. Modification of the model to the required locations is also possible using the GRASS GIS r.carve tool [15].
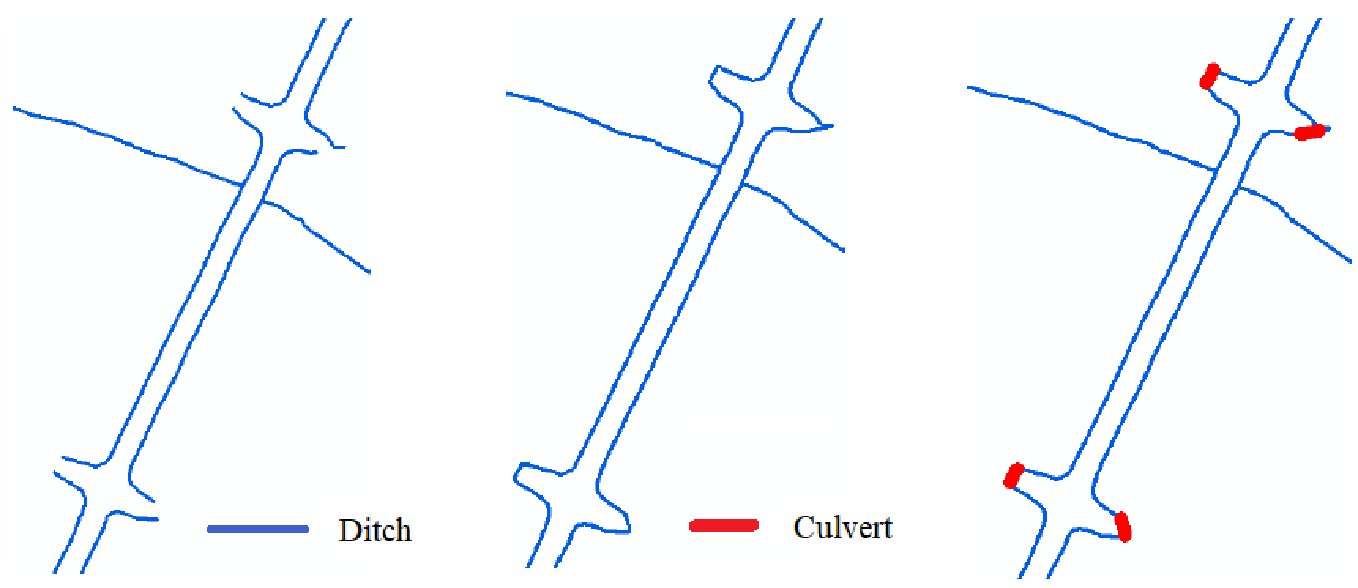

Fig. 2. Example of culvert identifying process 
The second method is based on automatic processing of the digital elevation model using algorithms [13; 16] in Whitebox GAT software such as Breach Depressions. This algorithm looks for the flow lines in the terrain model and automatically performs elevation decrement on the road, similar to Burn streams at roads (Fig. 3). For this algorithm, it is possible to set the minimum and maximum absolute descent values at which intervals the elevation is to be decreased. It should be noted that this tool has been developed in Canada [16], in more steep terrain, where natural flow lines are also more definite and use of this tool is limited in flat terrain.
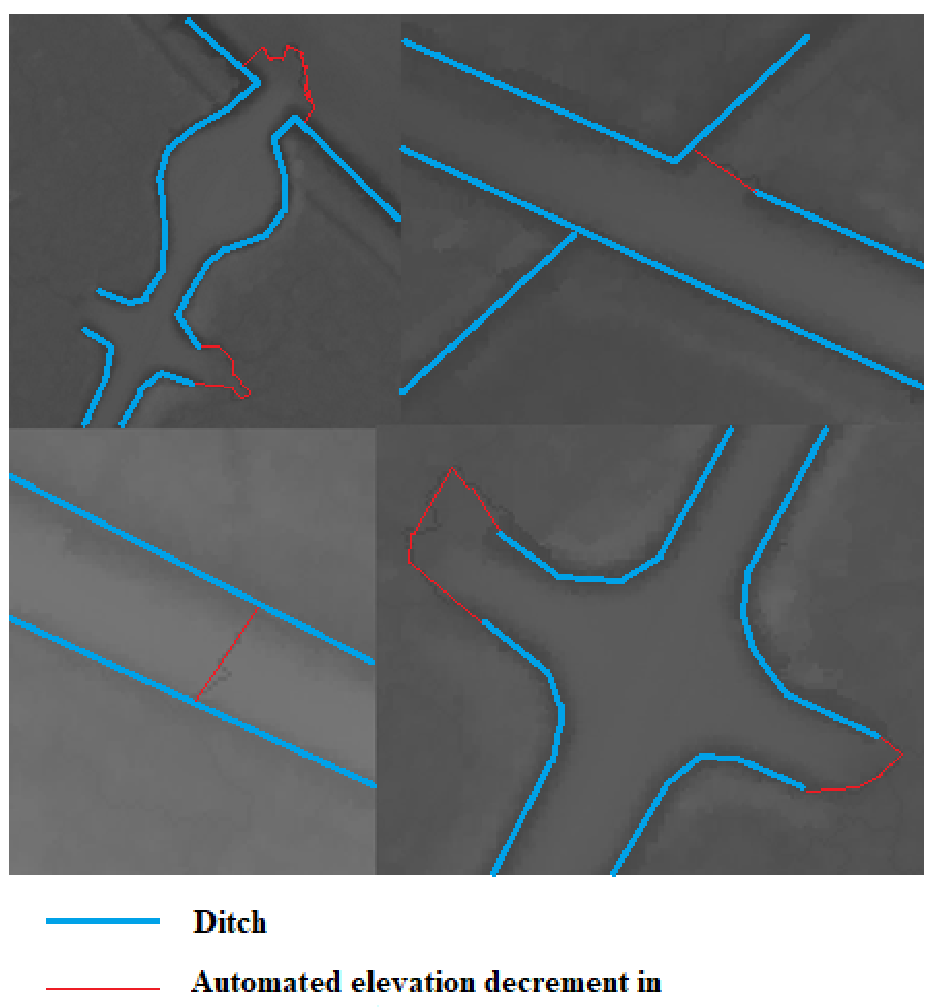
culvert location

Fig. 3. Examples of located culverts using Breach Depressions algorithm

Breach depressions algorithm is used in DEM horizontal resolutions of $0.5 \mathrm{~m}, 1 \mathrm{~m}$ and $2 \mathrm{~m}$, assuming that man-made artefacts in elevation model (road and rail embankments, bridges) are definitely wider than two meters. To compare and analyze the data sets, an error matrix of $5 \mathrm{~m}$ and 10 $\mathrm{m}$ in the buffer around the JSC Latvian State Forests database culverts, as well as culvert location data obtained from field surveys, was used. Estimation of used method efficiency is done using raster histogram to compare unwanted surface depression distributions which are formed as a result of unadjusted DEM in culvert locations.

\section{Results and discussion}

Using the first method, we identified 47 ditch connections that could correspond to culverts. Compared to the JSC Latvian State Forests database, there are 38 culverts in this area, which are mapped. To compare the obtained data with the database and the situation in the field, coordinates of culvert locations were collected during fieldworks. The survey of the culverts from the database in the pilot area found 23 of the 25 objects, or $92 \%$. Estimating the accuracy of the obtained data, it is concluded that out of the 47 automatically identified culverts within a $5 \mathrm{~m}$ radius of the database culverts, there are 14 culverts, which in this case is $30 \%$ of the total number of identified connection points and $37 \%$ of those in the database.

According to Fig. 4, the area of depressions, specified in logarithmic scale raster cell count, using both DEM correcting methods can be decreased significantly, but still it is the smallest part, according to the reference histogram. These depressions, with depth about maximum 1.4 meters are not related 
with ditch network, because in this case, in all culvert locations elevation decrements are made. Our used methods have decreased area of these false depressions till depth of about $2.5 \mathrm{~m}$.

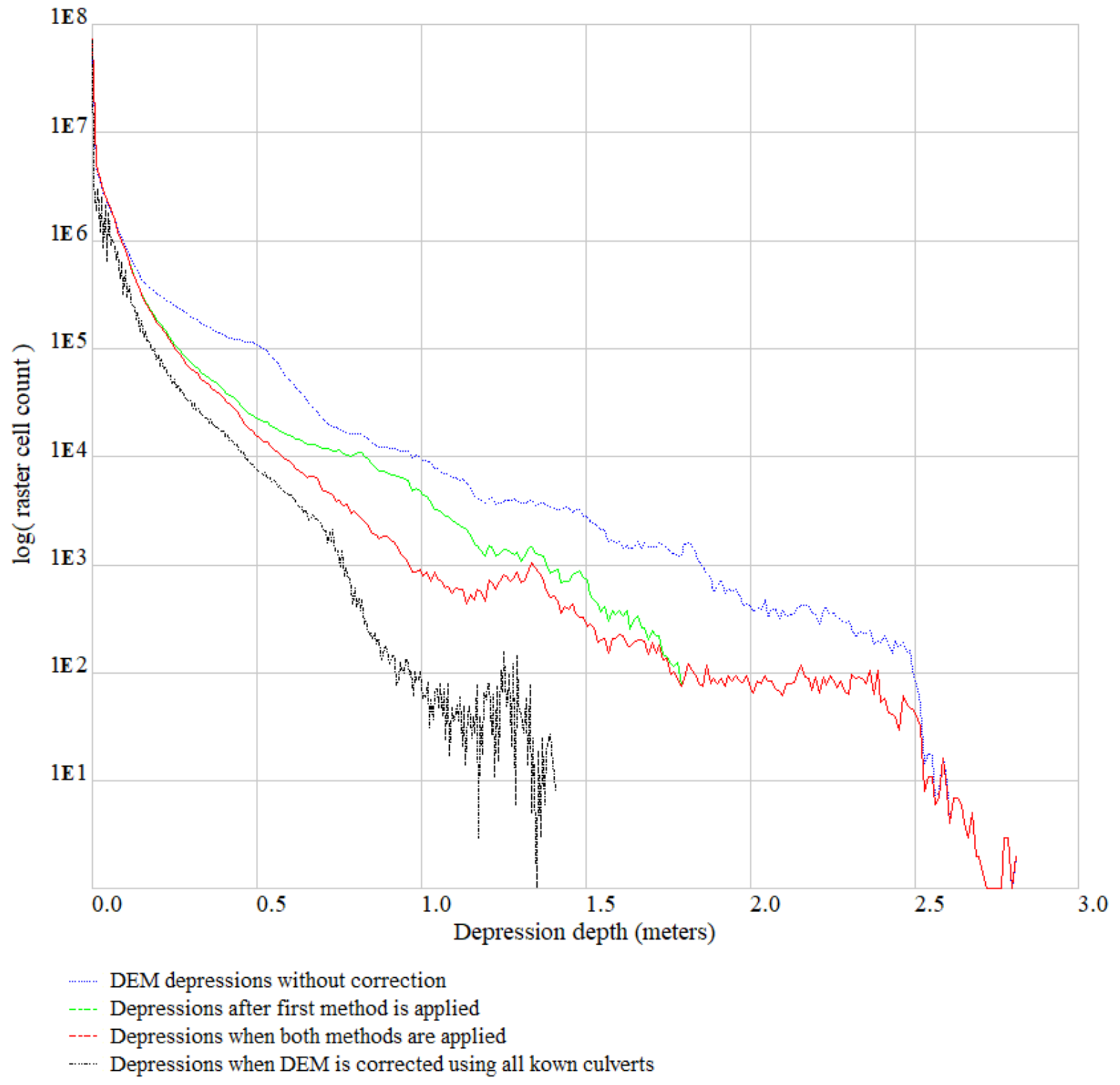

Fig. 4. Histogram of surface depression distribution depending on method applied

Using the Breach Depressions algorithm, DEM resolution is $1 \mathrm{~m}$ and $2 \mathrm{~m}$. In this resolution, the model does not produce many small outcrops, in the size of some raster cells, compared to a resolution of $0.5 \mathrm{~m}$, thus speeding up the tool. Testing the suitability of this tool in the pilot area confirmed its developers view that its performance is limited in flat terrain. Breach Depressions tool encountered problems with identifying culverts in areas without definite flow lines and making corrections in areas, where drainage is disturbed and not associated with ditches and paths, which can be a useful feature in further research. In this way, corrections to the DEM have been made at 12 locations that coincide with the locations of the culverts in the database. The total number of automatic adjustments and their significance is difficult to determine. Of these 12 culverts, 4 are those that failed to be identified by the first method using ditch network data, meaning that $47 \%$ of the culverts that match the database have been identified by applying both methods to the pilot area.

Identification of culverts was previously performed by the Belgian research team [8], where the location of approximately $30 \%$ of culverts was identified in the selected area. This study is not comparable to ours, because both studies have different approaches and different physical conditions 
in the study area. Account should also be taken of important factors, such as the maximum length of the culvert set up to $100 \mathrm{~m}$ in the study and the area selected. In our case, there is one study area in forest, which covers an area of 2500 ha, compared with 150 ha in the Belgian study and maximum culvert length set to $25 \mathrm{~m}$.

\section{Conclusions}

1. The study concludes that automatic identification of culvert locations using a digital elevation model and various GIS-based tools is feasible, but still faces many challenges to provide sufficient accuracy.

2. Accuracy of the method can be improved, by using current knowledge, if several methods are combined to identify connections.

3. The method, which is based on the analysis of the ditch network derived from LiDAR data, is perspective, but its accuracy needs to be improved. Existing algorithms, such as Breach Depressions, are applicable to Latvian conditions with some caution, clearly defining the expected result and what the revised DEM is intended to.

4. False surface depression area can be decreased significantly using these both automated DEM correction methods.

5. Using the current study results in the adjustment of DEM before hydrological modelling may inevitably require manual adjustments to it, given that less than half of the culverts have been identified. The method for identifying culverts is applicable in Latvian conditions to find culverts in cases, where a ditch is crossed by a road or a roadside ditch has an exit to field or forest.

6. This method does not identify culverts in situations, where ditches are placed parallel to one another and are incapable of intersecting at a given distance. This method needs to be refined, and further research on creek identification needs to be undertaken to collect more field data.

\section{Acknowledgements}

The study is implemented within the scope of the European Union LIFE Programme project "Demonstration of climate change mitigation potential of nutrient rich organic soils in Baltic States and Finland" (LIFE OrgBalt, LIFE18 CCM/LV/001158)"

\section{References}

[1] Orlandini S., Moretti G. Determination of surface flow paths from gridded elevation data: SURFACE FLOW PATHS FROM GRIDDED ELEVATION DATA. Water Resources Research, 45(3), 2009. DOI: 10.1029/2008WR007099

[2] Tarboton D. G. A new method for the determination of flow directions and upslope areas in grid digital elevation models. Water Resources Research, 33(2), 1997, pp. 309-319. DOI: 10.1029/96WR03137

[3] Yong-He L., Wan-Chang Z., Jing-Wen X. Another Fast and Simple DEM Depression-Filling Algorithm Based on Priority Queue Structure. Atmospheric and Oceanic Science Letters, 2(4), 2009, pp. 214-219. DOI: 10.1080/167 42834.2009 .11446800

[4] Lindsay John B., Creed I. F. Removal of artifact depressions from digital elevation models: Towards a minimum impact approach. Hydrological Processes, 19(16), 2005, pp. 3113-3126. DOI: 10.1002/hyp.5835

[5] Martz L. W., Garbrecht J. An outlet breaching algorithm for the treatment of closed depressions in a raster DEM. Computers \& Geosciences, 25(7), 1999, pp. 835-844. DOI: 10.1016/S00983004(99)00018-7

[6] Barber C. P., Shortridge A. Lidar Elevation Data for Surface Hydrologic Modeling: Resolution and Representation Issues. Cartography and Geographic Information Science, 32(4), 2005, pp. 401-410.

[7] Callow J. N., Van Niel K. P., Boggs G. S. How does modifying a DEM to reflect known hydrology affect subsequent terrain analysis? Journal of Hydrology, 332(1-2), 2007, pp. 30-39. DOI: $10.1016 /$ j.jhydrol.2006.06.020

[8] Roelens J., Van Orshoven J., Dondeyne S., Diels J. Extraction and connection of artificial drainage networks in agricultural areas using LiDAR data. Communications in agricultural and 
applied biological sciences. National Symposium on Applied Biological Sciences. Leuven, Belgium, 2017, p. 19.

[9] Roelens J., Rosier I., Dondeyne S., Van Orshoven J., Diels J. Extracting drainage networks and their connectivity using LiDAR data. Hydrological Processes, 32(8), 2018, pp. 1026-1037. DOI: 10/gdgpgf

[10] Cazorzi F., Fontana G. D., Luca A. D., Sofia G., Tarolli P. Drainage network detection and assessment of network storage capacity in agrarian landscape. Hydrological Processes, 27(4), 2013, pp. 541-553. DOI: 10/fxtdrx

[11]Le P. V., Kumar P. Power law scaling of topographic depressions and their hydrologic connectivity. Geophysical Research Letters, 41(5), 2014, pp. 1553-1559. DOI: 10.1002/2013GL059114

[12] Sofia G., Fontana G. D., Tarolli P. High-resolution topography and anthropogenic feature extraction: Testing geomorphometric parameters in floodplains: LIDAR DTMS AND ANTHROPOGENIC FEATURE EXTRACTION. Hydrological Processes, 28(4), 2014, pp. 20462061. DOI: 10.1002/hyp.9727

[13] Schwanghart W., Groom G., Kuhn N. J., Heckrath G. Flow network derivation from a highresolution DEM in a low relief, agrarian landscape. Earth Surface Processes and Landforms, 38(13), 2013, pp. 1576-1586. DOI: 10.1002/esp.3452

[14]Latvian Geospatial Information Agency. (2019). Aero laser scanning. LGIA. [online][11.02.2020] Available at: http://map.lgia.gov.lv/index.php?lang=0\&cPath=4_5\&txt_id=126

[15] Mitasova H., Mitas L., Brown W.M., Johnston D.J. Terrain modeling and Soil Erosion Simulations for Fort Hood and Fort Polk test areas. Report for CERL, 1999. [online][11.02.2020] Available at: https://grass.osgeo.org/grass78/manuals/r.carve.html

[16] Lindsay J.B., Dhun K. Modelling surface drainage patterns in altered landscapes using LiDAR. International Journal of Geographical Information Science, 29(3), 2015, pp. 397-411. DOI: $10.1080 / 13658816.2014 .975715$ 